\title{
Sepsis Diagnostics in the Era of "Omics" Technologies
}

\author{
Miroslav Průcha ${ }^{1}$, Roman Zazula ${ }^{2}$, Stefan Russwurm ${ }^{3}$ \\ ${ }^{1}$ Department of Clinical Biochemistry, Haematology and Immunology, \\ Na Homolce Hospital, Prague, Czech Republic; \\ ${ }^{2}$ Department of Anesthesiology and Intensive Care, First Faculty of Medicine, \\ Charles University and Thomayer Hospital, Prague, Czech Republic; \\ ${ }^{3}$ Department of Anesthesiology and Intensive Care, University Hospital Jena, \\ Jena, Germany \\ Received December 5, 2017; Accepted March 19, 2018.
}

Key words: Sepsis - Genomics - Transcriptomics - Proteinomics Metabolomics - Pharmacogenomics - Diagnostics

\begin{abstract}
Sepsis is a multifactorial clinical syndrome with an extremely dynamic clinical course and with high diverse clinical phenotype. Early diagnosis is crucial for the final clinical outcome. Previous studies have not identified a biomarker for the diagnosis of sepsis which would have sufficient sensitivity and specificity. Identification of the infectious agents or the use of molecular biology, next gene sequencing, has not brought significant benefit for the patient in terms of early diagnosis. Therefore, we are currently searching for biomarkers, through "omics" technologies with sufficient diagnostic specificity and sensitivity, able to predict the clinical course of the disease and the patient response to therapy. Current progress in the use of systems biology technologies brings us hope that by using big data from clinical trials such biomarkers will be found.
\end{abstract}

This study was supported by the Czech Republic Ministry of Health's conceptual development of research organisation (Nemocnice Na Homolce - NNH, 00023884, IG144101 and Thomayerova nemocnice - TN, 00064190).

Mailing Address: Assoc. Prof. Miroslav Průcha, MD., PhD., Department of Clinical Biochemistry, Haematology and Immunology, Na Homolce Hospital, Roentgenova 2, 15030 Prague 5, Czech Republic; Phone: +420 257273 051; e-mail: miroslav.prucha@homolka.cz 


\section{Introduction}

When Friedrich Miescher published a work on nuclein in 1869, nobody was aware of where this development in the medical field would go in the next 140 years (Dahm, 2010). In 1953, Watson and Crick only needed one DIN4 page to publish their groundbreaking work on the discovery of DNA structure (Watson and Crick, 1953). This discovery heralded the explosion of new findings related to research into the relation between the genome and its effect on the development and course of diseases. The beginning of the $21^{\text {st }}$ century saw an unprecedented development of systemic biology. This scientific field in biology uses knowledge in mathematics, biochemistry, chemistry and informatics to study complex interactions present in biological systems. Its expansion was made possible by the development of technology used for obtaining genomic and proteomic data and information technology (IT) development. These technologies provide us with new knowledge in medicine in terms of disease diagnosis and pathogenesis and therapy. So-called precision medicine is the final product (Figure 1). Molecular profiling and the use of therapies that target a specific disease's genetic traits are the two pillars of this approach. The most spectacular progress was made in oncology and hemato-oncology (Ginsburg and Willard, 2009; Bombard et al., 2013; Ciardiello et al., 2014; Yu and Snyder, 2016), in other medical fields, we witness their large dissemination and gradual implementation into clinical practice. Significant progress has also been achieved in the diagnostics and further research of sepsis pathogenesis in the last 20 years. But, despite investments of several billion euros (EUR) by the pharmaceutical industry in the last decades, only one new drug so far has made it to the market (Toft and Tønnesen, 2011; Marshall, 2014). Our review provides an overview of the current situation in using "omics" technologies (genomics, transcriptomics, proteinomics, metabolomics, pharmacogenomics) in the diagnostics and its possible impact to the therapy of septic patients.

\section{Sepsis}

Sepsis is among the leading causes of death worldwide. It accounts for more than 210,000 deaths annually in the United States, whereas similar death rates are reported for other countries (Angus et al., 2001; Shen et al., 2010; Kumar et al., 2011; Rhee et al., 2017). In Germany, it is the third most frequent cause of death in the German population and already the leading cost factor in German intensive care medicine with total costs of EUR 1.7 billion per year (Brunkhorst and Reinhart, 2005). It affects all age groups and it is the leading cause of morbidity and mortality in critically ill patients following intensive care unit (ICU) admission. Mortality from sepsis seems unchanged despite intense efforts in intensive care management of the patient. Mortality of sepsis is currently higher than that of myocardial infarction; even worse outcomes are revealed when patients with septic shock are considered (Esper and Martin, 2007). Martin et al. (2009) analysed more than 11,000 patients included in the international registry comprising severe sepsis 


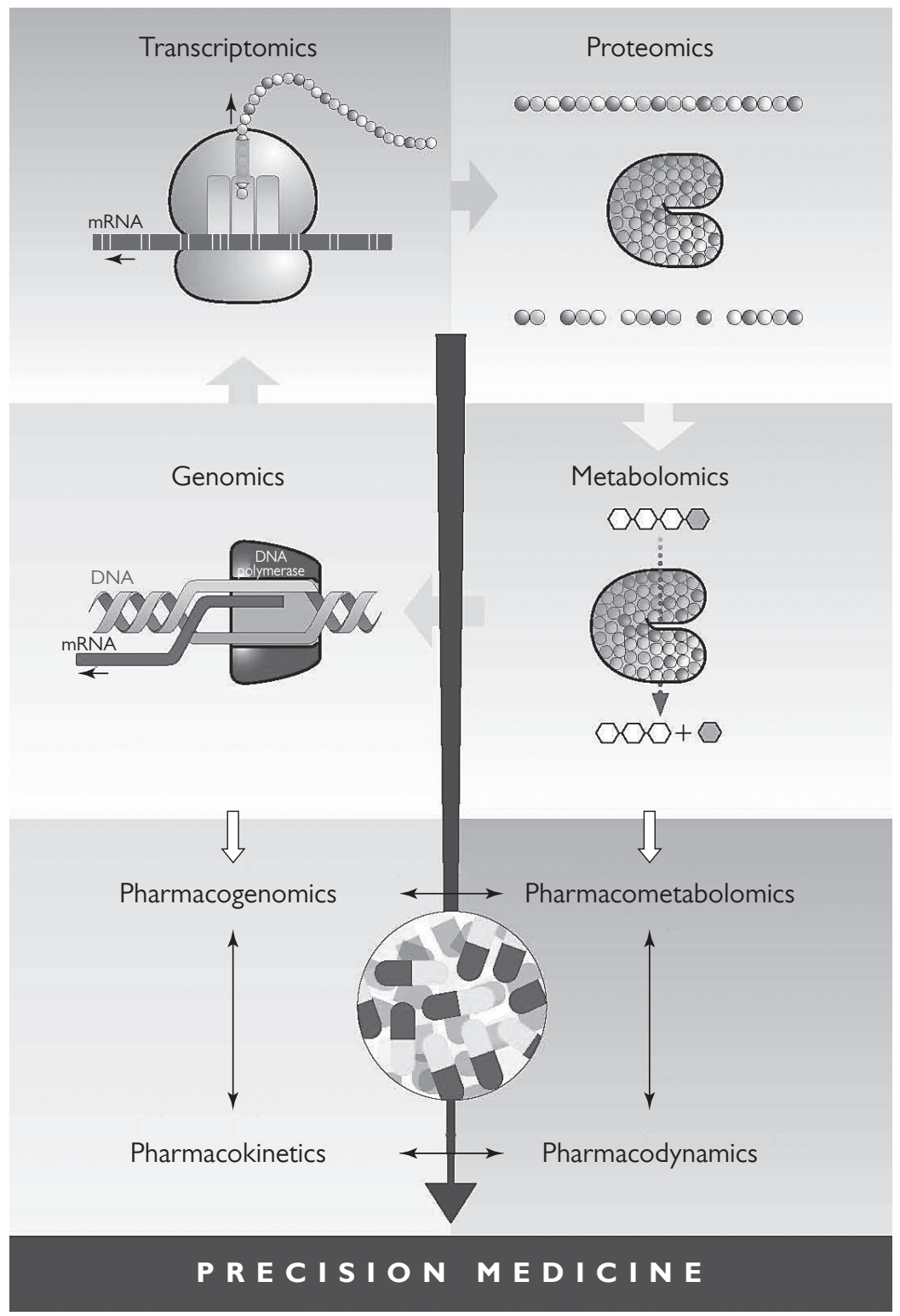

Figure 1 - Precision medicine as a result of omics technologies.

cases. The total mortality reached almost 50\%. The European Sepsis Occurrence in Acutely III Patients (SOAP) study revealed that the incidence of sepsis in European ICUs is $33 \%$ with an overall mortality of $27 \%$ (Vincent et al., 2006). In the past decades, progress has been made in the education, prevention, identification, treatment and rehabilitation of septic patients. All of these important advancements 
together have gradually ameliorated the individual burden of sepsis; nevertheless, it remains unacceptably high. Moreover, due to the ever-growing incidence of sepsis, the overall number of patients who die from sepsis continues to increase (Adhikari et al., 2010; Jawad et al., 2012; Martin, 2012; De La Rica et al., 2016). Very important aspect is impact of socioeconomic status on mortality and morbidity in patients with sepsis (Schnegelsberg et al., 2016). It is not surprising that the scientific community continues to call for improved treatment options, including a timely diagnosis and active surveillance in hospitalized patients at high risk for the development of sepsis.

Present state of the art in the field - science and methodology In the pathogenesis of sepsis, the key player is the dysregulation of the mechanisms of innate and adaptive immunity. A local inflammatory response progresses into a systemic response, reflecting a failure of the immunological compensatory mechanisms. Traditionally, sepsis is considered an exaggerated inflammatory response of the host to a bacterial invader (Calandra et al., 2000; Cavaillon et al., 2003; Huang et al., 2010; van Vught et al., 2017). As such, it is conceived that monitoring of the inflammatory host response may provide critical information for diagnosis and prognosis. A plethora of circulating proteins has been studied in the last 20 years as probable surrogate markers of the physical course of sepsis. Their use is based on the rationale that since inflammation results from a bacterial stimulus, changes of a biomarker or a combination of biomarkers may reflect eradication or propagation of the infection site. However, none of the studied biomarkers is considered an absolute reflection of the inflammatory state of the host and none has yet reached wide routine use (Biron et al., 2015; Prucha et al., 2015).

In the process of evolution, the innate immune system has developed many mechanisms that are capable of recognizing a pathogenic organism and responding to its presence accordingly. Furthermore, these mechanisms are capable of identifying homeostasis disrupting stimuli of a non-infectious nature (e.g. ischemia, trauma). For this purpose, immunocompetent cells possess pattern recognition receptors (PRRs) that are capable of recognizing characteristic pathogen associated molecular patterns (PAMPs). Upon interaction of PAMPs and PRRs, adaptor proteins come into play whose task is to activate transcription factors (Kono and Rock, 2008; van der Poll and Opal, 2008; Kumar et al., 2009a). Adaptor proteins activate the transcription factors, including nuclear factor $\mathrm{KB}$ (NF-KB), activation protein-1 (AP-1) and interferon response factor (IRF). The activation results in the expression of genes for pro- and anti-inflammatory cytokines (Medzhitov, 2001; Wiel et al., 2002; Akira et al., 2006). When severe sepsis becomes clinically apparent, the host has already entered into a state of immunoparalysis where circulating monocytes are no longer able to secrete pro-inflammatory cytokines, antigen presentation fails and apoptosis of lymphocytes predominates (Ayala et al., 
2003; López-Collazo et al., 2006; Biswas et al., 2007; del Fresno et al., 2008, 2009).

Indeed, most of the studied potential biomarkers in severe sepsis, capable to reflect immune system mode and inflammatory cascade stage(s), are protein molecules with downregulated gene expression. Under this understanding of timely non-coordinated and yet overlapping counter-balancing processes of pro-inflammatory trigger and immunoparalysis follow-up stage, it is obvious that circulatory proteins are not the ideal surrogate biomarkers for sepsis. The underlying transcription of the genetic machinery of the host, which precedes translation and post-translational modifications of functionally ready proteins in time, occurs faster and reflects initial regulatory mechanisms necessary for the final protein output; and is then expected to provide more important information (Feezor et al., 2005). Novel "biomarkers" are urgently needed to identify correctly and timely the "infection" as the underlying cause of a systemic host response, because each hour of delay of anti-infectious therapy leads to a $5 \%$ increase in mortality (Kumar et al., 2009b). A sensitive biomarker is desirable when the consequences of missing the diagnosis are important; vice versa, a specific measure is desirable when costs or potential side effects of treatment are considerable. Both aspects are important in the context of sepsis where missed infections will double mortality rates, and antibiotic overuse is associated with rising resistance but also other problem such as organ toxicity, development of Clostridium difficile infection, etc. Therefore, it is important for the clinician to know when antibiotics can be safely withheld. While single proteins are useful biomarkers in a variety of well-characterized diseases, such as troponin for the early detection of myocardial infarction, new biomarker candidates for complex clinical syndromes such as sepsis cannot reliably discriminate non-infectious from infectious systemic inflammation. Procalcitonin, which probably best meets the requirements for a biomarker of infection at present, is hampered by false positives in the setting of non-infectious inflammation and a rather late induction during the host response to infection (Becker et al., 2008; Sager et al., 2017). Recently clinical studies were published on the relationship between presepsin and sepsis. Presepsin levels are increased in septic patients with no significant difference between patients with gram-positive or gram-negative infection. Presepsin appears to be very early biomarker of sepsis with place in the clinical diagnostics and may be of interest for future studies (Carpio et al., 2015; Zhang et al., 2015). As the complexity of the host response makes it unlikely that one single biomarker can adequately describe and stratify this complex syndrome, response patterns come into play. Because changes in the signalling of effector cells of innate immunity represent the earliest event in the "infection-host response-continuum", lab-on-a-chip assays addressing multiple "omics" levels and analysing sets of biomarkers that reflect these changed patterns can meet this need. Such an approach promises not only to substantially improve sensitivity and specificity but also to shorten the time to diagnosis and therapy. 
The role of "omics" technologies in sepsis research:

1) Diagnostics of sepsis - to find biomarkers differentiating infectious and non-infectious inflammation

2) To find biomarkers predicting the clinical outcome

3) To find biomarkers that offer the possibility for the therapy of sepsis

4) To find biomarkers predicting patient response to therapy

\section{Genomics and epigenomics}

On 26 June 2000, Celera Genomics and the International Human Genome Sequencing Consortium (HGSC) announced the completion of the first assembly of the human genome and the completion of the rough draft, respectively. In February of 2001, two teams simultaneously published their analyses of the genome sequences generated (Lander et al., 2001; Venter et al., 2001). At present, we know that human genome contains approximately 22,000 genes that code proteins and 5-10 times more proteins are formed as their final product. The price of human genome research has been immense - approximately 3 billion US dollars. In the last 15 years, new technologies such as next gene sequencing (ngs) dramatically reduced the price and, thus, the availability of complete genetic information. New technologies provide for a faster and more complex approach $(\mathrm{Ng}$ and Kirkness, 2010). At present, it is possible to map the genome of an individual cell (Gawad et al., 2016; Hynes et al., 2017). However, the beginnings of the relation between genomics and infections date back to a more distant past. In 1988, Sørensen and colleagues demonstrated that the risk of dying from infectious disease was five times higher if an individual's biological parent had also died of infectious disease. Since then, numerous studies have attempted to associate genetic markers of genomic variation (polymorphisms) with incidence or outcome of infectious disease and its sequelae in critically ill patients. Tumour necrosis factor (TNF) gene polymorphisms showed association with an increased incidence as well as adverse outcomes in patients with severe sepsis and septic shock (Stüber et al., 1996). Similarly pro- and anti-inflammatory cytokines like the interleukin-1 (IL-1) gene family, interleukin-6 (IL-6) and interleukin-10 (IL-10) are associated with different outcomes of septic patients (Fang et al., 1999). Genomic variants of candidate genes involved in pathogen recognition and signal transduction of inflammatory pathways like CD14, Toll-like receptors (TLRs), lipopolysaccharide binding protein (LBP), interleukin-1 receptor-associated kinase (IRAK 4), IRAK 1 may also contribute to the incidence, severity and mortality of infectious complications in the critically ill (Hubacek et al., 2001; Feterowski et al., 2003; Medvedev et al., 2003; Sutherland et al., 2005; Arcaroli et al., 2006; Khor et al., 2007; Chien et al., 2008; Mansur et al., 2015). In addition, it has been recognized that protein cascades involved in the pathophysiology of sepsis, such as the coagulation cascade, represent strong genomic candidate markers for association studies (Hermans et al., 1999). In a recent study, German authors conducted GWAS in a cohort of 
740 adult patients with sepsis. They found 14 loci with suggestive evidence for an association with 28-day mortality and found supportive, converging evidence for three of them in independent data sets. Authors have concluded that elucidating the underlying biological mechanisms of VPS13A, CRISPLD2, and the chromosome 13 locus should be a focus of future research activities (Scherag et al., 2016). A study performed by Rautanen et al. (2015) revealed interesting results. Authors identified variants in the FER gene, which are associated with a reduced risk of death from sepsis due to pneumonia. The FER gene encodes non-receptor protein tyrosine kinase. Tyrosine kinase is an enzyme from the protein kinase group, which catalyzes the transfer of a phosphate group (phosphorylation) from nucleoside triphosphate (mostly ATP) to the amino acid tyrosine in proteins. Non-receptor tyrosine kinases function in the cytoplasm and transfer signals within the cell into the nucleus (Gocek et al., 2014). The FER gene affects leukocyte recruitment and intestinal barrier dysfunction caused by lipopolysaccharide (LPS) (Parsons et al., 2007). Srinivasan et al. (2017) studied single nucleotide polymorphisms with sepsis in a cohort of 757 prematurely born children. The authors concluded that they did not find a significant association between single nucleotide polymorphism (SNP) and sepsis, however, areas of the potential association and pathways meriting for further study were identified. Sapru et al. (2016) proved association of common genetic variation in the protein $C$ pathway genes with clinical outcomes in acute respiratory distress syndrome. The Netherland study provides a method for the molecular classification of patients with sepsis to 4 different endotypes upon ICU admission. Detection of sepsis endotypes might assist in providing personalized patient management and in selection for trials (Scicluna et al., 2017). Current results show that sepsis is a multifactorial disease, which is not necessarily related to a certain gene of a group of genes and/or their variants. Patients with primary immunodeficiency who are sensitive to certain types of infection are an exception (Feezor et al., 2005; Bustamante et al., 2014). Gene activity varies due to different epigenetic mechanisms. The mechanisms involve DNA modification by methylation and histone modification. Histone modifications represent acetylation, ubiquitination and phosphorylation. Both histone modifications and DNA cytosine methylation have been shown to regulate gene expression (Esteller, 2007; Dong and Weng, 2013). The main principle is the gene expression variability without a change in DNA sequence (Phillips, 2008). The example of this phenomenon is the bacteriahost interaction. Bacterium-induced epigenetic deregulations may affect host cell function either to promote host defence or to allow pathogen persistence. Thus, pathogenic bacteria can be considered as potential epimutagens able to reshape the epigenome (Bierne et al., 2012; Stephens et al., 2013).

\section{Transcriptomics}

Transcriptomics evaluates messenger RNA levels for genes in specific cells or tissues. Transcriptomics aims at monitoring gene activity and regulation, 
differentiating infectious and non-infectious inflammation, finding pathogenetic mechanisms and parameters that will predict clinical outcome. A number of issues arise in these studies dealing with sepsis. The first one is the enormous dynamics of disease progression in sepsis. From the pathogenetic point of view, sepsis is characterized by the concurrent presence of pro-inflammatory and antiinflammatory phases that translates into immunosuppression (Boomer et al., 2011; Xiao et al., 2011; Hotchkiss et al., 2013; Cazalis et al., 2014). However, the clinical course of sepsis shows that in its early stages, pro-inflammatory elements are dominant and characterized by high production of pro-inflammatory cytokines, which at a later time lead to functional immunosuppression. Therefore, gene expression is likely to differ according to the development of sepsis over time (Leentjens et al., 2013). Another issue that we have to deal with when studying sepsis, is the target tissue of the organ in which gene expression is to be measured. It is not possible to harvest tissue in septic patients for ethical reasons; therefore, our data are based on measurements of the best available analyte - full blood and/or individual blood cell subpopulations. It is clearly not a bad alternative from the pathogenetic point of view because full blood, with all its immunocompetent cells, represents a robust and complex immunological mechanism involved in sepsis pathogenesis (Leliefeld et al., 2016). On the other hand, it is a potential source of possible erroneous conclusions. The reasons for this are multiple (starting with the patient's age) children vs. adults (immaturity of the immune system vs. a large number of co-morbidities in elderly patients who represent the majority of patients dying from sepsis) and different gene expression depending on cell subpopulations (e.g. neutrophils, NK cells and lymphocytes). A study by Palmer et al. (2006) revealed different gene expression, depending on the subpopulation of immunocompetent cells. Study by Parnell et al. (2013) measuring gene expression in full blood identified genes with immune dysfunction in septic patients. Practically, no study has been performed that would evaluate gene expression in individual organs during clinical sepsis, with the exception of experimental studies (Cobb et al., 2002).

Differentiation of infectious and non-infectious SIRS, pathogenetic mechanisms of sepsis The first studies evaluated gene expression in volunteers who received an endotoxin dose (Calvano et al., 2005; Talwar, 2006). They found a different expression in volunteers who received endotoxin and identified target gene groups with their bonds in gene maps. Since the beginning, the limits of experimental endotoxin use were clear compared with clinical sepsis with a living infectious agent. One of the first clinical study performed in patients with sepsis that confirmed different gene expression in systemic inflammatory response syndrome (SIRS) of infectious and non-infectious etiology was published in 2004 (Prucha et al., 2004). The results were confirmed by other studies (Johnson et al., 2007; Lissauer et al., 2009; Seok et al., 2013; Sweeney et al., 2015). Differences were 
found with respect to the septic agent. While a study by Tang et al. (2008) did not reveal a different gene expression in gram-positive $\left(\mathrm{G}^{+}\right)$and gram-negative (G-) infections, a study by Yu et al. (2004) obtained different results. When studying gene expression, attention is paid to mechanisms characterizing inflammation of infectious etiology and disease severity. A study by Grealy et al. (2013) revealed different gene expression of IL-2, IL-10, IL-23, IL-27, interferon- $\gamma$ (IFN $\gamma$ ) and $\mathrm{TNF} \alpha$, based on whether it was an infection or severe sepsis. A study performed by Hinrichs et al. (2010) identified genes, the expression of which predicts postoperative sepsis. Significant differences $(P<0.005)$ in gene expression between the 2 groups were observed for IL1B (interleukin 1, beta), TNF [tumour necrosis factor (TNF superfamily, member 2)], CD3D [CD3d molecule, delta (CD3-TCR complex)] and PRF1 [perforin 1 (pore forming protein)]. The combination of $T N F, I L 1 B$ and CD3D expression had a sensitivity and specificity of $90 \%$ and $85 \%$, respectively, and predicted exclusion of postoperative sepsis with an estimated negative predictive value of $98.1 \%$ (Hinrichs et al., 2010). Different gene expression was demonstrated in bacterial and virus infections related to immune dysfunction. Authors identified a T-cell-dominant gene-expression signature that is associated with the host response to severe influenza pneumonia. Genes linked to the cell cycle and its regulation were the main determinants of the host response in influenza infection. Interestingly study failed to identify an immune response specific to bacterial pneumonia (Parnell et al., 2012). A study by Sampson et al. (2017) which revealed different gene expression depending on virus or bacterial etiology, produced similar results. Should these abilities of a specific group of genes be confirmed, there is a real possibility of their implementation in clinical practice, which would affect antibiotic consumption, resistance development, etc. Another very recent study revealed individual predisposition of septic patients with regard to the final outcome and prognosis. Davenport et al. (2016) analysed gene expression of peripheral blood leucocytes in ICU patients who were admitted for sepsis caused by community acquired pneumonia and evidence of organ dysfunction. Transcriptomic analysis defined two different pictures - so-called sepsis response signature (SRS). SRS1 found in $41 \%$ of patients, identified patients with an immunosuppression phenotype (endotoxin tolerance, T-cell exhaustion and human leukocyte antigen (HLA) class II regulation disorder). This phenotype was associated with higher 14-day mortality (Davenport et al., 2016). In 2014, Fiusa et al. published a meta-analysis of gene expression in severe sepsis and septic shock. From 45 studies out of 22,216 probe sets, authors observed 352 as candidates (215 of which were upregulated and 137 downregulated). The top 5 up-regulated genes were CD177, MMP8, HP, ARG1 and ANXA3. The top downregulated genes were FCER1A, YMEI1L1,TRDV3, LRRN3 and MYBL1 (Fiusa et al., 2014). In response to a need for better sepsis diagnostics, several new gene expression classifiers have been recently published, including the 11-gene "Sepsis MetaScore", the "FAIM3-to-PLAC8" ratio and the Septicyte Lab. The three diagnostics do not 
show significant differences in overall ability to distinguish non-infectious SIRS from sepsis (Sweeney and Khatri, 2017). On the other hand, the study of Zimmerman et al. (2017) showed that the Septicyte Lab test is able to discriminate between clinically severe sepsis syndrome and infection-negative systemic inflammation among critically ill children.

\section{Proteomics}

We differentiate between express proteomics detecting proteins, which are characteristic of sepsis, and functional proteomics, which identifies proteomic markers and their function on the molecular level. A key role is played by the type of technology used. At present, there are two-dimensional differential gel electrophoresis (2D-DIGE), matrix-associated laser desorption/ionization-time of flight (MALDI-TOF), surface-enhanced laser desorption/ionization-time of flight (SELDI-TOF), laser capture microdissection-MS (LCM-MS) and protein microarray (Mesri, 2014). It should be noted that different technological platforms do not provide the same results. There is only a partial overlap between the biomarkers identified by individual technologies. This of course makes the verification of results more difficult. In addition to genomics, proteomics is a significant means of precision medicine that advances diagnostics and disease treatment a large step ahead. Similar objectives are followed here to find new biomarkers, which will differentiate infectious systemic inflammation from non-infectious systemic inflammation, and to find pathogenetic mechanisms that could be implemented in clinical practice with regard to diagnostics and treatment. Buhimschi used 2D-DIGE and mass spectrometry to study umbilical blood proteome in order to find biomarkers that could identify patients with an early onset of sepsis. The authors found that a switch-on in haptoglobin to haptoglobin-related protein expression reflected a fetal adaptive response to intraamniotic infection exposure in utero (Buhimschi et al. 2011). A study Paugam-Burtz et al. (2010) identified new proteins detected in patients following liver transplant and sepsis. This study used plasma profiling coupling protein chip array with SELDI-TOF. In the validation set of 31 patients with infection and 34 without infection, the 5 peaks were differentially expressed as well and allowed day 5 sepsis diagnosis with a positive likelihood ratio of 5.1 and C-statistics of 0.74 (0.58-0.85) (Paugam-Burtz et al., 2010). Proteomics is used to study infectious model and describe protein-protein interactions. A Swedish study using mass spectrometry maps the interaction between bacterial and plasma proteins. Using Streptococcus pyogenes as an infectious agent and adhered human blood plasma protein, the author constructed a stoichiometric model of protein structure interaction. The model and knowledge of these constructions will help to better understand protein-protein interactions and their importance for bacterial virulence (Sjöholm et al., 2017). Another Swedish study based on an experimental sepsis model with virulent Streptococcus pyogenes in mice maps proteins in blood plasma and individual organs. The results not only showed 
a partial overlapping of proteins in individual organs but also protein abundance levels, which differ in different organs (Malmström et al., 2016). These findings confirmed the results of previous studies (Huttlin et al., 2010; Geiger et al., 2013).

\section{Metabolomics}

Metabolomics is the large-scale study of small molecules (commonly known as metabolites) within cells, fluids, tissues or organisms. Collectively, these small molecules and their interactions within a biological system are known as the metabolome. Metabolomics is the study of substrates and products of metabolism, which are influenced by both genetic and environmental factors (Kosmides et al., 2013). Metabolomics is a powerful approach because metabolites and their concentrations, unlike other "omics" measures, directly reflect the underlying biochemical activity and state of cells/tissues. Thus, metabolomics best represents the molecular phenotype (Serkova et al., 2011; Patti et al., 2012). The Human Metabolome Database contains records for more than 42,000 metabolites, from sugars to peptides to cofactors. But the total may be significantly higher, and single analytical methods often struggle to capture the chemical diversity. Current technologies can even analyse a metabolome in one cell. With regard to the immense heterogeneity of cell populations, the question is whether this approach can bring about significant progress (Fessenden, 2016). The aims of metabolomics are the same as with other "omics" technologies - diagnosis, prognosis and identification of at risk patients. Swedish authors published an interesting study. In a prospective study, whole blood samples from 65 patients with bacteremic sepsis and 49 controls were compared. The blood samples were analysed using gas chromatography coupled to time-of-flight mass spectrometry. A 6-metabolite predictive logistic regression model showed a sensitivity of 0.91 ( $95 \%$ confidence interval $(\mathrm{Cl}) 0.69-0.99)$ and a specificity of $0.84(95 \% \mathrm{Cl} 0.58-0.94)$ with an area under curve (AUC) of 0.93 (95\% Cl 0.89-1.01). Myristic acid was the single most predictive metabolite, with a sensitivity of $1.00(95 \% \mathrm{Cl} 0.85-1.00)$ and specificity of 0.95 (95\% Cl 0.74-0.99), and performed better than various combinations of conventional laboratory and clinical parameters (Kauppi et al., 2016).

Ambrogio examined urine metabolome in an infant with fatal methicillin resistant Staphylococcus aureus (MRSA) pneumonia, 4 children with influenza pneumonia (pneumonia control group) and 7 healthy children with no known infections. Urine metabolite concentrations previously identified as associated with sepsis in children (e.g. 3-hydroxybutyrate, carnitine and creatinine) were higher in the patient with fatal MRSA pneumonia compared with those of patients with influenza pneumonia and healthy controls. The concentrations of additional metabolites (acetone, acetoacetate, choline, fumarate, glucose and 3-aminoisobutyrate) were more than 25-fold higher in the patient with MRSA pneumonia than those of patients with influenza pneumonia and healthy controls. These metabolic changes in the urine preceded the clinically severe sepsis phenotype, suggesting that detection 
of the extent of metabolic disruption can aid in the early identification of a sepsis phenotype in advance of the clinical diagnosis (Ambroggio et al., 2017). In other study, Ferrario et al. (2016) examined plasma metabolome and clinical features in a subset of 20 patients with severe septic shock. Early changes in the plasma levels of low unsaturated long-chain phosphatidylcholines and kynurenine were associated with mortality (Ferrario et al., 2016). A urine metabolomic analysis in terms of the patient's prognosis was also performed by the authors of a Spanish study. Urine samples were collected from 64 patients with severe sepsis or septic shock in the ICU.Authors compared the prediction power of metabolomics data respect with respect to Sequential Organ Failure Assessment (SOFA) score. Supervised multivariate analysis afforded a good predictive model to distinguish the patient groups and to detect specific metabolic patterns. Negative prognosis patients presented higher values of ethanol, glucose and hippurate, and, on the contrary, lower levels of methionine, glutamine, arginine and phenylalanine (Garcia-Simon et al., 2015). And finally, a Chinese study provides the proteomic analysis of urine to identify prognostic biomarkers of sepsis. The 7 identified proteins provide insight into the mechanism of sepsis. Low urinary lysosome-associated membrane protein-1 levels may be useful for the early prognostic assessment of sepsis (Su et al., 2013). Su et al. (2013) described the metabolic profile of normal patients and patients with SIRS or sepsis, which was markedly different. Seven metabolites may potentially be used to diagnose sepsis. A significant decrease in the levels of lactitol dehydrate and S-phenyl-D-cysteine and an increase in the levels of $\mathrm{S}$-(3-methylbutanoyl)-dihydrolipoamide-E and $\mathrm{N}$-nonanoyl glycine were observed in patients with sepsis in comparison to patients with SIRS $(P<0.05)$. Patients with severe sepsis and septic shock displayed lower levels of glyceryl-phosphorylethanolamine, $\mathrm{Ne}, \mathrm{Ne}$ dimethyllysine, phenylacetamide and $\mathrm{D}$-cysteine $(\mathrm{P}<0.05)$ in their sera (Su et al., 2014).

\section{Pharmacogenomics - Pharmacometabolomics}

"Omics" technologies are developing further. They result not only in identifying new biomarkers, new knowledge of disease pathogenesis and prediction of the clinical course of disease and outcomes in patients but have also direct consequences for research dealing with drug efficiency. Pharmacogenomics and pharmacometabolomics provide tools for mapping the effects of drugs on metabolism and for identifying pathways that contribute to drug response variation (Kaddurah-Daouk et al., 2015). In septic patients, only a few studies were presented. Man et al. (2013) conducted a GWAS using a large randomised clinical trial cohort to discover genetic biomarkers of response to therapy in septic patients. Evidence for gene-gene interactions were identified for sepsis treatment responses with genetic biomarkers dominating models for predicting therapeutic response (Man et al., 2013). Study of Puskarich et al. (2015) shows a unique metabolite profile of L-carnitine responders in patients with septic shock. 
Pharmacometabolomics has clear potential for the future in predicting patients' reactions to individual drugs (Everett, 2016; Huan et al., 2017; Rattray and Kaddurah Daouk, 2017).

Limitations of the use of omics technology in sepsis

Sepsis, as a systemic expression of a pathological response of the immune system to infection, is an extremely complex and dynamic process. Unlike chronic inflammatory autoimmune diseases and oncological diseases, whose preclinical and clinical progression is relatively long and enables current use of omics technology findings both in diagnostics and therapy, sepsis is a clinical syndrome the trigger mechanism of which still fails to be identified. It is already possible to identify some biomarkers, which predict a higher risk of adverse outcomes in these patients. The use of increasingly better technologies including the evaluation of "big data" raises hope that we will be able to use precise medicine even with them. As the example of chronic inflammatory autoimmune diseases shows (e.g. rheumatoid arthritis (RA) or Crohn disease) they are, on the basis of molecular analyses, differentiated to new subtypes or various nosologic units with different patient's phenotype and with different pathogenesis resulting presumably in different therapeutic approaches (Li and Kauffman, 2014; Smolen et al., 2016;Wang et al., 2017; Weiser et al., 2018).

\section{Conclusion}

At present, omics technologies represent significant technological progress in the further study of sepsis pathogenesis, its relation with genetic predisposition and a pathway to more effective pharmacotherapy. So far, there is no practical use in sepsis diagnosis and treatment, but it seems to be a very hopeful and promising journey. Omics data can be a powerful tool for patient diagnostics, stratification and therapy similar to patients with traumatic and thermal injury (Hazeldine et al., 2016). In addition, the recent discovery of CRISPR-Cas9 (clustered regularly interspaced short palindromic repeats-CRISPR associated protein 9) and their specific use in disease diagnostics and treatment having a significant predictive value for genetic predisposition is revolutionary (Gootenberg et al., 2017; Patel et al., 2017).

\section{References}

Adhikari, N. K., Fowle, R. A., Bhagwanjee, S., Rubenfeld, G. D. (2010) Critical care and the global burden of critical illness in adults. Lancet 376, 1339-1346.

Akira, S., Uematsu, S., Takeuchi, O. (2006) Pathogen recognition and innate immunity. Cell 124, 783-801.

Ambroggio, L., Florin, T. A., Shah, S. S., Ruddy, R., Yeomans, L., Trexel, J., Stringer, K. A. (2017) Emerging biomarkers of illness severity: Urinary metabolites associated with sepsis and necrotizing methicillinresistant Staphylococcus aureus pneumonia. Pharmacotherapy 37, 1033-1042.

Angus, D. C., Linde-Zwirble, W. T., Lidicker, J., Clermont, G., Garcillo, J., Pinsky, M. R. (2001) Epidemiology of severe sepsis in the United States: analysis of incidence, outcome, and associated costs of care. Crit. Care Med. 29, 1303-1310.

Arcaroli, J., Silva, E., Maloney, J. P., He, Q., Svetkauskaite, D., Murphy, J. R., Abraham, E. (2006) Variant IRAK-1 
haplotype is associated with increased nuclear factor-kappa B activation and worse outcomes in sepsis. Am. J. Respir. Crit. Care Med. 173, 1335-1341.

Ayala, A., Lomas, J. L., Grutkoski, P. S., Grutkoski, P. S., Chung, C. S. (2003) Pathological aspects of apoptosis in severe sepsis and shock? Int. J. Biochem. Cell Biol. 35, 715-720.

Becker, K. L., Snider, R., Nylen, E. S. (2008) Procalcitonin assay in systemic inflammation, infection, and sepsis: clinical utility and limitations. Crit. Care Med. 6, 941-952.

Bierne, H., Hamon, M., Cossart, P. (2012) Epigenetics and bacterial infections. Cold Spring Harb. Perspect. Med. 2, a010272.

Biron, B. M., Ayala, A., Lomas-Neira, L. J. (2015) Biomarkers for sepsis:What is and what might be? Biomark. Insights 10(S4), 7-17.

Biswas, S. K., Bist, P., Dhillon, M. K., Kajiji, T., del Fresno, C., Yamamoto, M., Lopez-Collazo, E., Akira, S., Tergaonkar, V. (2007) Role for MyD88-independent, TRIF pathway in lipid A/TLR4-induced endotoxin tolerance. J. Immunol. 179, 4083-4092.

Bombard, Y., Bach, P. B., Offit, K. (2013) Translating genomics in cancer care. J. Natl. Compr. Canc. Netw. 11, 1343-1353.

Boomer, J. S., To, K., Chang, K. C., Takasu, O., Osborne, D. F., Walton, A. H., Bricker, T. L., Jarman, S. D., Kreisel, D., Krupnick, A. S., Srivastava, A., Swanson, P. E., Green, J. M., Hotchkiss, R. S. (2011) Immunosuppression in patients who die of sepsis and multiple organ failure. JAMA 306, 2594-2605.

Brunkhorst, F. M., Reinhart, K. (2005) German competence network for the study of severe sepsis and septic shock (SepNet). ICU Manag. Pract. 5.

Buhimschi, C. S., Bhandari, V., Dulay, A. T., Nayeri, U. A., Abdel-Razeq, S. S., Pettker, C. M., Thung, S., Zhao, G., Han, Y. W., Bizzarro, M., Buhimschi, I. A. (2011) Proteomics mapping of cord blood identifies haptoglobin "switch-on" pattern as biomarker of early-onset neonatal sepsis in preterm newborns. PLoS One 6, e26111.

Bustamante, J., Boisson-Dupuisa, S., Abela, L., Casanova, J. L. (2014) Mendelian susceptibility to mycobacterial disease: Genetic, immunological, and clinical features of inborn errors of IFN- $\gamma$ immunity. Semin. Immunol. 26, 454-470.

Calandra, T., Echtenacher, B., Roy, D. L., Pugin, J., Metz, N., Hültner, L., Heumann, D., Männel, D., Bucala, R., Glauser, M. P. (2000) Protection from septic shock by neutralization of macrophage migration inhibitory factor. Nat. Med. 6, 164-170.

Calvano, S. E., Xiao, W., Richards, D. R. (2005) A network-based analysis of systemic inflammation in humans. Nature 437, 1032-1037.

Carpio, R., Zapata, J., Spanuth, E., Hess, G. (2015) Utility of presepsin (sCD14-ST) as a diagnostic and prognostic marker of sepsis in the emergency department. Clin. Chim. Acta 450, 169-175.

Cavaillon, J. M., Adib-Conquy, M., Fitting, C., Adrie, C., Payen, D. (2003) Cytokine cascade in sepsis. Scand. J. Infect. Dis. 35, 535-544.

Cazalis, M. A., Lepape, A., Venet, F., Frager, F., Mougin, B., Vallin, H., Paye, M., Pachot, A., Monneret, G. (2014) Early and dynamic changes in gene expression in septic shock patients: a genome-wide approach. Intensive Care Med. Exp. 2, 20-37.

Chien, J.W., Boeckh, M. J., Hansen, J. A., Clark, J. G. (2008) Lipopolysaccharide binding protein promoter variants influence the risk for gram-negative bacteremia and mortality after allogeneic hematopoietic cell transplantation. Blood 111, 2462-2469.

Ciardiello, F., Arnold, D., Casali, P. G., Cervantes, J.Y., Douillard, A., Eggermont, A., Eniu, K., McGregor, S., Piccart, P. M., Popescu, R., Van Cutsem, E., Zielinski, R., Stahel, R. (2014) Delivering precision medicine in oncology today and in future-the promise and challenges of personalised cancer medicine: a position paper by the European Society for Medical Oncology (ESMO). Ann. Oncol. 25, 1673-1678.

Průcha M.; Zazula R.; Russwurm S. 
Cobb, J. P., Laramie, J. M., Stormo, G., Morrissey, J. J., Shannon, W. D., Qiu, Y., Karl, I. E., Buchman, T. G., Hotchkiss, R. S. (2002) Sepsis gene expression profiling: Murine splenic compared with hepatic responses determined by using complementary DNA microarrays. Crit. Care Med. 30, 2711-2721.

Dahm, R. (2010) From discovering to understanding. EMBO Rep. 11, 153-160.

Davenport, E. E., Burnham, K. L., Radhakrishnan, J., Humburg, P., Hutton, P., Mills, T. C., Rautanen, A., Gordon, A. C., Garrard, C., Hill, A. V., Hinds, C. J., Knight, J. C. (2016) Genomic landscape of the individual host response and outcomes in sepsis: a prospective cohort study. Lancet Respir. Med. 4, 259-271.

De La Rica, A. S., Gilsanz, F., Maseda, E. (2016) Epidemiologic trends of sepsis in western countries. Ann. Transl. Med. 4, 325-331.

del Fresno, C., Gómez-Piña, V., Lores, V., Soares-Schanoski, A., Fernández-Ruiz, l., Rojo, B., Alvarez-Sala, R., Caballero-Garrido, E., García, F., Veliz, T., Arnalich, F., Fuentes-Prior, P., García-Río, F., López-Collazo, E. (2008) Monocytes from cystic fibrosis patients are locked in an LPS tolerance state: down-regulation of TREM-1 as putative underlying mechanism. PLoS One 3, e2667.

del Fresno, C., García-Rio, F., Gómez-Piña,V., Soares-Schanoski, A., Fernández-Ruíz, I., Jurado, T., Kajiji, T., Shu, C., Marín, E., Gutierrez del Arroyo, A., Prados, C., Arnalich, F., Fuentes-Prior, P., Biswas, S. K., López-Collazo, E. (2009) Potent phagocytic activity with impaired antigen presentation identifying lipopolysaccharide-tolerant human monocytes: demonstration in isolated monocytes from cystic fibrosis patients. J. Immunol. 182, 6494-6507.

Dong, X., Weng, Z. (2013) The correlation between histone modifications and gene expression. Epigenomics 5, 113-116.

Esper, A., Martin, G. S. (2007) Is severe sepsis increasing in incidence and severity? Crit. Care Med. 35, 1414-1415.

Esteller, M. (2007) Cancer epigenomics: DNA methylomes and histone-modification maps. Nat. Rev. Genet. 8, 286-298.

Everett, J. R. (2016) From metabonomics to pharmacometabonomics: the role of metabolic profiling in personalized medicine. Front. Pharmacol. 7, 297.

Fang, X. M., Schröder, S., Hoeft, A., Stuber, F. (1999) Comparison of two polymorphisms of the interleukin-1 gene family: interleukin-1 receptor antagonist polymorphism contributes to susceptibility to severe sepsis. Crit. Care Med. 27, 1330-1334.

Feezor, R. J., Cheng, A., Paddock, H. N., Baker, H.V., Moldawer, L. L. (2005) Functional genomics and gene expression profiling in sepsis: beyond class prediction. Clin. Infect. Dis. 41, S427-S435.

Ferrario, M., Cambiaghi, A., Brunelli, L., Giordano, S., Caironi, P., Guatteri, L., Raimondi, F., Gattinoni, L., Latini, R., Masson, S., Ristagno, G., Pastorelli, R. (2016) Mortality prediction in patients with severe septic shock: a pilot study using a target metabolomics approach. Sci. Rep. 6, 20391.

Fessenden, M. (2016) Metabolomics: small molecules, single cells. Nature 540, 153-155.

Feterowski, C., Emmanuilidis, K., Miethke, T., Gerauer, K., Rump, M., Ulm, K., Holzmann, B., Weighardt, H. (2003) Effects of functional Toll-like receptor-4 mutations on the immune response to human and experimental sepsis. Immunology 109, 426-431.

Fiusa, M. M., Carvalho, B. S., Hubert, R. M., Souza, W., Lopes-Cendes, I., Annichino-Bizzacchi, J. M., De Paula, E.V. (2014) A meta-analysis of gene expression studies in severe sepsis and septic shock. Blood 124, 2741.

Garcia-Simon, M., Morales, J. M., Modesto-Alapont, V., Gonzalez-Marrachelli, V., Vento-Rehues, R., Jorda-Miñana, A., Blanquer-Olivas, J., Monleon, D. (2015) Prognosis biomarkers of severe sepsis and septic shock by $1 \mathrm{H}$ NMR urine metabolomics in the intensive care unit. PLoS One 10, e0140993.

Gawad, C., Koh,W., Quake, S. R. (2016) Single-cell genome sequencing: current state of the science. Nat. Rev. Genet. 17, 175-188. 
Geiger, T., Velic, A., Macek, B., Lundberg, E., Kampf, C., Nagaraj, N., Uhlen, M., Cox, J., Mannet, M. (2013) Initial quantitative proteomic map of 28 mouse tissues using the SILAC mouse. Mol. Cell. Proteomics 12, 1709-1722.

Ginsburg, G. S., Willard, H. F. (2009) Genomic and personalized medicine: foundations and applications. Transl. Res. 154, 277-287.

Gocek, E., Moulas, A. N., Studzinski, G. P. (2014) Non-receptor protein tyrosine kinases signaling pathways in normal and cancer cells. Crit. Rev. Clin. Lab. Sci. 51, 125-137.

Gootenberg, J. S., Abudayyeh, O. O., Lee, J.W., Essletzbichler, P., Dy, A. J., Joung, J., Verdine, V., Donghia, N., Daringer, N. M., Freije, C. A., Myhrvold, C., Bhattacharyya, R. P., Livny, J., Regev, A., Koonin, E.V., Hung, D. T., Sabeti, P. C., Collins, J. J., Zhang, F. (2017) Nucleic acid detection with CRISPR-Cas13a/C2c2. Science 356, 438-442.

Grealy, R., White, M., Stordeur, P., Kelleher, D., Doherty, D. G., McManus, R., Ryan, T. (2013) Characterising cytokine gene expression signatures in patients with severe sepsis. Mediators Inflamm. 2013, 164246.

Hazeldine, J., Hampson, P., Lord, J. M. (2016) The diagnostic and prognostic value of systems biology research in major traumatic and thermal injury: a review. Burns Trauma 4, 33-44.

Hermans, P.W., Hibberd, M. L., Booy, R., Daramola, O., Hazelzet, J. A., de Groot, R., Levin, M. (1999) 4G/5G promoter polymorphism in the plasminogen-activator-inhibitor-1 gene and outcome of meningococcal disease. Meningococcal Research Group. Lancet 354, 556-560.

Hinrichs, C., Kotsch, K., Buchwald, S., Habicher, M., Saak, N., Gerlach, H., Volk, H. D., Keh, D. (2010) Perioperative gene expression analysis for prediction of postoperative sepsis. Clin. Chem. 56, 613-622.

Hotchkiss, R. S., Monneret, G., Payen, D. (2013) Sepsis-induced immunosuppression: from cellular dysfunctions to immunotherapy. Nat. Rev. Immunol. 13, 862-874.

Huan, T., Forsberg, E. M., Rinehart, D., Johnson, C. H., Ivanisevic, J., Benton, H. P., Fang, M., Aisporna, A., Hilmers, B., Poole, F. L., Thorgersen, M. P., Adams, M.W.W., Krantz, G., Fields, M.W., Robbins, P. D., Niedernhofer, L. J., Ideker, T., Majumder, E. L., Wall, J. D., Rattray, N. J.W., Goodacre, R., Lairson, L. L., Siuzdak, G. (2017) Systems biology guided by XCMS online metabolomics. Nat. Methods 14, 461-462.

Huang, W., Tang, Y., Li, L. (2010) HMGB1, a potent proinflammatory cytokine in sepsis. Cytokine 51, 119-126. Hubacek, J. A., Stüber, F., Fröhlich, D., Book, M., Wetegrove, S., Ritter, M., Rothe, G., Schmitz, G. (2001) Gene variants of the bactericidal/permeability increasing protein and lipopolysaccharide binding protein in sepsis patients: gender-specific genetic predisposition to sepsis. Crit. Care Med. 29, 557-561.

Huttlin, E. L., Jedrychowski, M. P., Elias, J. E., Goswami, T., Rad, R., Beausoleil, S. A., Villén, J., Haas, W., Sowa, M. E., Gygi, S. P. (2010) A tissue-specific atlas of mouse protein phosphorylation and expression. Cell 143, 1174-1189.

Hynes, S. O., Pang, B., James, J. A., Maxwell, P., Salto-Tellez, M. (2017) Tissue-based next generation sequencing: application in a universal healthcare system. Br. J. Cancer 116, 553-560.

Jawad, I., Luksic, I., Rafnsson, S. B. (2012) Assessing available information on the burden of sepsis: global estimates of incidence, prevalence and mortality. J. Glob. Health 2, 010404.

Johnson, S. B., Lissauer, M., Bochicchio, G.V., Moore, R., Cross, A. S., Scalea, T. M. (2007) Gene expression profiles differentiate between sterile SIRS and early sepsis. Ann. Surg. 245, 611-621.

Kaddurah-Daouk, R.,Weinshilboum, R.; Pharmacometabolomics Research Network (2015) Metabolomic signatures for drug response phenotypes: Pharmacometabolomics enables precision medicine. Clin. Pharmacol. Ther. 98, 71-75.

Kauppi, A. M., Edin, A., Ziegler, I., Mölling, P., Sjösted, A., Gylfe, A., Strålin, K., Johansson, A. (2016) Metabolites in blood for prediction of bacteremic sepsis in the emergency room. PLoS One 11, e0147670.

Khor, C. C., Chapman, S. J., Vannberg, F. O., Dunne, A., Murphy, C., Ling, E. Y., Frodsham, A. J., Walley, A. J., Kyrieleis, O., Khan, A., Aucan, C., Segal, S., Moore, C. E., Knox, K., Campbell, S. J., Lienhardt, C., Scott, A., 
Aaby, P., Sow, O.Y., Grignani, R. T., Sillah, J., Sirugo, G., Peshu, N., Williams, T. N., Maitland, K., Davies, R. J., Kwiatkowski, D. P., Day, N. P., Yala, D., Crook, D.W., Marsh, K., Berkley, J. A., O’Neill, L. A., Hill, A. V. (2007) A Mal functional variant is associated with protection against invasive pneumococcal disease, bacteremia, malaria and tuberculosis. Nat. Genet. 39, 523-528.

Kono, H., Rock, K. L. (2008) How dying cells alert the immune system to danger. Nat. Rev. Immunol. 8, $279-289$. Kosmides, A. K., Kamisoglu, K., Calvano, S. E., Corbett, S. A., Androulakis, I. P. (2013) Metabolomic fingerprinting: challenges and opportunities. Crit. Rev. Biomed. Eng. 41, 205-221.

Kumar, A. T., Sudhir, U., Punith, K., Kumar, R., Kumar, V. N., Rao, M.Y. (2009a) Cytokine profile in elderly patients with sepsis. Indian J. Crit. Care Med. 13, 74-78.

Kumar, A., Ellis, P., Arabi, Y., Roberts, D., Light, B., Parrillo, J. E., Dodek, P., Wood, G., Kumar, A., Simon, D., Peters, C., Ahsan, M., Chateau, D.; Cooperative Antimicrobial Therapy of Septic Shock Database Research Group (2009b) Initiation of inappropriate antimicrobial therapy results in a fivefold reduction of survival in human septic shock. Chest 136, 1237-1248.

Kumar, G., Kumar, A., Taneja, A., Kaleekal, T., Tarima, S., McGinley, E., Jimenez, E., Mohan, A., Khan, R. A., Whittle, J., Jacobs, E., Nanchal, R.; Milwaukee Initiative in Critical Care Outcomes Research (MICCOR) Group of Investigators (2011) Nationwide trends of severe sepsis in the $21^{\text {st }}$ century (2000-2007). Chest 140 , 1223-1231.

Lander, E. S., Linton, L. M., Birren, B., Nusbaum, C., Zody, M. C., Baldwin, J., Devon, K., Dewar, K., Doyle, M., FitzHugh, W., Funke, R., Gage, D., Harris, K., Heaford, A., Howland, J., Kann, L., Lehoczky, J., LeVine, R., McEwan, P., McKernan, K., Meldrim, J., Mesirov, J. P., Miranda, C., Morris, W., Naylor, J., Raymond, C., Rosetti, M., Santos, R., Sheridan, A., Sougnez, C., Stange-Thomann, Y., Stojanovic, N., Subramanian, A., Wyman, D., Rogers, J., Sulston, J., Ainscough, R., Beck, S., Bentley, D., Burton, J., Clee, C., Carter, N., Coulson, A., Deadman, R., Deloukas, P., Dunham, A., Dunham, I., Durbin, R., French, L., Grafham, D., Gregory, S., Hubbard, T., Humphray, S., Hunt, A., Jones, M., Lloyd, C., McMurray, A., Matthews, L., Mercer, S., Milne, S., Mullikin, J. C., Mungall, A., Plumb, R., Ross, M., Shownkeen, R., Sims, S., Waterston, R. H., Wilson, R. K., Hillier, L.W., McPherson, J. D., Marra, M. A., Mardis, E. R., Fulton, L. A., Chinwalla, A. T., Pepin, K. H., Gish, W. R., Chissoe, S. L., Wendl, M. C., Delehaunty, K. D., Miner, T. L., Delehaunty, A., Kramer, J. B., Cook, L. L., Fulton, R. S., Johnson, D. L., Minx, P. J., Clifton, S. W., Hawkins, T., Branscomb, E., Predki, P., Richardson, P., Wenning, S., Slezak, T., Doggett, N., Cheng, J. F., Olsen, A., Lucas, S., Elkin, C., Uberbacher, E., Frazier, M., Gibbs, R. A., Muzny, D. M., Scherer, S. E., Bouck, J. B., Sodergren, E. J., Worley, K. C., Rives, C. M., Gorrell, J. H., Metzker, M. L., Naylor, S. L., Kucherlapati, R. S., Nelson, D. L., Weinstock, G. M., Sakaki, Y., Fujiyama, A., Hattori, M., Yada, T., Toyoda, A., Itoh, T., Kawagoe, C., Watanabe, H., Totoki, Y., Taylor, T., Weissenbach, J., Heilig, R., Saurin, W., Artiguenave, F., Brottier, P., Bruls, T., Pelletier, E., Robert, C., Wincker, P., Smith, D. R., Doucette-Stamm, L., Rubenfield, M., Weinstock, K., Lee, H. M., Dubois, J., Rosenthal, A., Platzer, M., Nyakatura, G., Taudien, S., Rump, A., Yang, H., Yu, J., Wang, J., Huang, G., Gu, J., Hood, L., Rowen, L., Madan, A., Qin, S., Davis, R. W., Federspiel, N. A., Abola, A. P., Proctor, M. J., Myers, R. M., Schmutz, J., Dickson, M., Grimwood, J., Cox, D. R., Olson, M.V., Kaul, R., Raymond, C., Shimizu, N., Kawasaki, K., Minoshima, S., Evans, G. A., Athanasiou, M., Schultz, R., Roe, B. A., Chen, F., Pan, H., Ramser, J., Lehrach, H., Reinhardt, R., McCombie, W. R., de la Bastide, M., Dedhia, N., Blöcker, H., Hornischer, K., Nordsiek, G., Agarwala, R., Aravind, L., Bailey, J. A., Bateman, A., Batzoglou, S., Birney, E., Bork, P., Brown, D. G., Burge, C. B., Cerutti, L., Chen, H. C., Church, D., Clamp, M., Copley, R. R., Doerks, T., Eddy, S. R., Eichler, E. E., Furey, T. S., Galagan, J., Gilbert, J. G., Harmon, C., Hayashizaki, Y., Haussler, D., Hermjakob, H., Hokamp, K., Jang, W., Johnson, L. S., Jones, T. A., Kasif, S., Kaspryzk, A., Kennedy, S., Kent, W. J., Kitts, P., Koonin, E.V., Korf, I., Kulp, D., Lancet, D., Lowe, T. M., McLysaght, A., Mikkelsen, T., Moran, J.V., Mulder, N., Pollara, V. J., Ponting, C. P., Schuler, G., Schultz, J., Slater, G., Smit, A. F., Stupka, E., Szustakowki, J., Thierry-Mieg, D., Thierry-Mieg, J., Wagner, L., Wallis, J., Wheeler, R., 
Williams, A., Wolf, Y. I., Wolfe, K. H., Yang, S. P., Yeh, R. F., Collins, F., Guyer, M. S., Peterson, J., Felsenfeld, A., Wetterstrand, K. A., Patrinos, A., Morgan, M. J., de Jong, P., Catanese, J. J., Osoegawa, K., Shizuya, H., Choi, S., Chen, Y. J., Szustakowki, J.; International Human Genome Sequencing Consortium (2001) Initial sequencing and analysis of the human genome. Nature 409, 860-921.

Leentjens, J., Kox, M., van der Hoeven, J. G., Netea, M. G., Pickkers, P. (2013) Immunotherapy for the adjunctive treatment of sepsis: from immunosuppression to immunostimulation. Time for a paradigm change? Am. J. Respir. Crit. Care Med. 187, 1287-1293.

Leliefeld, H. F., Wessels, C. M., Leenan, L. P., Koenderman, L., Pillay, J. (2016) The role of neutrophils in immune dysfunction during severe inflammation. Crit. Care 20, 73-82.

Li, Y. R., Kauffman, J. M. (2014) Molecular medicine of rheumatoid arthritis: From molecular pathophysiology to novel therapeutics and evidence-based practice. Ann. Orthop. Rheumatol. 2, 1014-1024.

Lissauer, M. E., Johnson, S. B., Bochicchio, G.V., Carinda, J., Feild, A. S., Cross, J. D., Hasday, C. C., Whiteford,W. A., Nussbaumer, M. T., Scalea, T. (2009) Differential expression of Toll-like receptor genes: sepsis compared with sterile inflammation 1 day before sepsis diagnosis. Shock 31, 238-244.

López-Collazo, E., Fuentes-Prior, P., Arnalich, F., del Fresno, C. (2006) Pathophysiology of interleukin-1 receptor-associated kinase-M: implications in refractory state. Curr. Opin. Infect. Dis. 19, 237-244.

Malmström, E., Kilsgård, O., Hauri, S., Smeds, E., Herwald, H., Malmström, L., Malmström, J. (2016) Large-scale inference of protein tissue origin in gram-positive sepsis plasma using quantitative targeted proteomics. Nat. Commun. 7, 10261.

Man, M., Close, S. L., Shaw, A. D., Bernard, G. R., Douglas, I. S., Kaner, R. J. (2013) Beyond single-marker analyses: Mining whole genome scans for insights into treatment responses in severe sepsis. Pharmacogenomics J. 13, 218-226.

Mansur, A., Liese, B., Steinau, M., Ghadimi, M., Bergmann, I., Tzvetkov, M., Popov, A. F., Beissbarth, T., Bauer, M., Hinz, J. (2015) The CD14 rs2569190 TT genotype is associated with an improved 30-days survival in patients with sepsis: a prospective observational study. PLoS One 10, e0127761.

Marshall, J. C. (2014) Why have clinical trials in sepsis failed? Trends Mol. Med. 20, 195-203.

Martin, G. S. (2012) Sepsis, severe sepsis and septic shock: Changes in incidence, pathogens and outcomes. Expert Rev. Anti Infect. Ther. 10, 701-706.

Martin, G., Brunkhorst, F. M., Janes, J. M., Reinhart, K., Sundin, D. P., Garnett, K., Beale, R. (2009) The international PROGRESS registry of patients with severe sepsis: drotrecogin alfa (activated) use and patients outcomes. Crit. Care 13, R103.

Medvedev, A. E., Lentschat, A., Kuhns, D. B., Blanco, J. C., Salkowski, C., Zhang, S., Arditi, M., Gallin, J. I., Vogel, S. N. (2003) Distinct mutations in IRAK-4 confer hyporesponsiveness to lipopolysaccharide and interleukin-1 in a patient with recurrent bacterial infections. J. Exp. Med. 198, 521-531.

Medzhitov, R. (2001) Toll-like receptors and innate immunity. Nat. Rev. Immunol. 1, 135-139.

Mesri, M. (2014) Advances in proteomic technologies and its contribution to the field of cancer. Adv. Med. 2014, 238045.

Ng, P. C., Kirkness, E. F. (2010) Whole genome sequencing. Methods Mol. Biol. 628, 215-226.

Palmer, C., Diehn, M., Alizadeh, A. A., Brown, P. O. (2006) Cell-type specific gene expression profiles of leukocytes in human peripheral blood. BMC Genomics 7, 115-130.

Parnell, G. P., McLean, A. S., Booth, D. R., Armstrong, N. J., Nalos, M., Huang, S. J., Manak, J., Tang, W., Tam, O.Y., Chan, S., Tang, B. M. (2012) A distinct influenza infection signature in the blood transcriptome of patients with severe community-acquired pneumonia. Crit. Care 16, R157.

Parnell, G. P., Tang, B. M., Nalos, M., Armstrong, N. J., Huang, S. J., Booth, D. R., McLean, A. S. (2013) Identifying key regulatory genes in the whole blood of septic patients to monitor underlying immune dysfunctions. Shock 40, 166-174.

Průcha M.; Zazula R.; Russwurm S. 
Parsons, S. A., Mewburn, J. D., Truesdell, P., Greer, P. A. (2007) The Fps/Fes kinase regulates leucocyte recruitment and extravasation during inflammation. Immunology 122, 542-550.

Patel, S. J., Sanjana, N. E., Kishton, R. J., Eidizadeh, A., Vodnala, S. K., Cam, M., Gartner, J. J., Jia, L., Steinberg, S. M., Yamamoto, T. N., Merchant, A. S., Mehta, G. U., Chichura, A., Shalem, O., Tran, E., Eil, R., Sukumar, M., Guijarro, E. P., Day, C. P., Robbins, P., Feldman, S., Merlino, G., Zhang, F., Restifo, N. P. (2017) Identification of essential genes for cancer immunotherapy. Nature 548, 537-542.

Patti, G. J., Yanes, O., Siuzdak, G. (2012) Innovation: Metabolomics: The apogee of the omics trilogy. Nat. Rev. Mol. Cell Biol. 13, 263-269.

Paugam-Burtz, C., Albuquerque, M., Baron, G., Bert, F., Voitot, H., Delefosse, D., Dondero, F., Sommacale, D., Francoz, C., Hanna, N., Belghiti, J., Ravaud, P., Bedossa, P., Mantz, J., Paradis, V. (2010) Plasma proteome to look for diagnostic biomarkers of early bacterial sepsis after liver transplantation: a preliminary study. Anesthesiology 112, 926-935.

Phillips, T. (2008) The role of methylation in gene expression. Nature Education 1, 116.

Prucha, M., Ruryk, A., Boriss, H., Möller, E., Zazula, R., Herold, I., Claus, R. A., Reinhart, K. A., Deigner, P., Russwurm, S. (2004) Expression profiling: Toward an application in sepsis diagnostics. Shock 22, 29-33.

Prucha, M., Bellingan, G., Zazula, R. (2015) Sepsis biomarkers. Clin. Chim. Acta 440, 97-104.

Puskarich, M. A., Finkel, M. A., Karnowsky, A., Jones, A. E., Trexel, J., Harris, B. N., Stringer, K. A. (2015) Pharmacometabolomics of L-carnitine treatment response phenotypes in patients with septic shock. Ann. Am. Thorac. Soc. 12, 46-56.

Rattray, N. J., Kaddurah Daouk, R. (2017) Pharmacometabolomics and precision medicine special issue editorial. Metabolomics 13, 59.

Rautanen, A., Mills, T. C., Gordon, A. C., Hutton, P., Steffens, M., Nuamah, R., Chiche, J. D., Parks, T., Chapman, S. J., Davenport, E. E., Elliott, K. S., Bion, J., Lichtner, P., Meitinger, T., Wienker, T. F., Caulfield, M. J., Mein, C., Bloos, F., Bobek, I., Cotogni, P., Sramek, V., Sarapuu, S., Kobilay, M., Ranieri, V. M., Rello, J., Sirgo, G., Weiss, Y. G., Russwurm, S., Schneider, E. M., Reinhart, K., Holloway, P.A., Knight, J. C., Garrard, C. S., Russell, J. A., Walley, K. R., Stüber, F., Hill, A.V., Hinds, C. J.; ESICM/ECCRN GenOSept Investigators (2015) Genome-wide association study of survival from sepsis due to pneumonia: an observational cohort study. Lancet Respir. Med. 3, 53-60.

Rhee, C., Dantes, R., Epstein, L., Murphy, D. J., Seymour, C.W., Iwashyna, T. J., Kadri, S. S., Angus, D. C., Danner, R. L., Fiore, A. E., Jernigan, J. A., Martin, G. S., Septimus, E., Warren, D. K., Karcz, A., Chan, C., Menchaca, J. T., Wang, R., Gruber, S., Klompas, M.; CDC Prevention Epicenter Program (2017) Incidence and trends of sepsis in US hospitals using clinical vs. claims data, 2009-2014. JAMA 318, 1241-1249.

Sager, R., Kutz, A., Mueller, B., Schuetz, P. (2017) Procalcitonin-guided diagnosis and antibiotic stewardship revisited. BMC Med. 15, 15-26.

Sampson, D. L., Fox, B. A., Yager, T. D., Bhide, S., Cermelli, L. C., McHugh, T. A., Seldon, R. A., Brandon, E., Sullivan, J. J., Zimmerman, M., Noursadeghi, R. B. (2017) A four-biomarker blood signature discriminates systemic inflammation due to viral infection versus other etiologies. Sci. Rep. 7, 2914.

Sapru, A., Liu, K. D., Wiemels, J., Hansen, H., Pawlikowska, L., Poon, A., Jorgenson, E., Witte, J. S., Calfee, C. S., Ware, L. B., Matthay, M. A.; NHLBI ARDS Network (2016) Association of common genetic variation in the protein $C$ pathway genes with clinical outcomes in acute respiratory distress syndrome. Crit. Care 20, 151-161.

Scherag, A., Schöneweck, F., Kesselmeier, M., Taudien, S., Platzer, M., Felder, M., Sponholz, C., Rautanen, A., Hill, A.V. S., Hinds, C. J., Hossain, H., Suttorp, N., Kurzai, O., Slevogt, H., Giamarellos-Bourboulis, E. J., Armaganidis, A., Trips, E., Scholz, M., Brunkhorst, F. M. (2016) Genetic factors of the disease course after sepsis: a genome-wide study for 28 day mortality. EBioMedicine 12, 239-246. 
Schnegelsberg, A., Mackenhauer, J., Nibro, H. L., Dreyer, P., Koch, K., Kirkengaard, H. (2016) Impact of socioeconomic status on mortality and unplanned readmission in septic intensive care unit patients. Acta Anaesthesiol. Scand. 60, 465-475.

Scicluna, B. P., van Vught, L. A., Zwinderman, A. H., Wiewel, M. A., Davenport, E. E., Burnham, K. L., Nürnberg, P., Schultz, M. J., Horn, J., Cremer, O. L., Bonten, M. J., Hinds, C. J., Wong, H. R., Knight, J. C., van der Poll, T.; MARS Consortium (2017) Classification of patients with sepsis according to blood genomic endotype: a prospective cohort study. Lancet Respir. Med. 5, 816-826.

Seok, J., Warren, H. S., Cuenca, A. G., Mindrinos, M. N., Baker, H.V., Xu, W., Richards, D. R., McDonald-Smith, G. P., Gao, H., Hennessy, L., Finnerty, C. C., López, C. M., Honari, S., Moore, E. E., Minei, J. P., Cuschieri, J., Bankey, P. E., Johnson, J. L., Sperry, J., Nathens, A. B., Billiar, T. R., West, M. A., Jeschke, M. G., Klein, M. B., Gamelli, R. L., Gibran, N. S., Brownstein, B. H., Miller-Graziano, C., Calvano, S. E., Mason, P. H., Cobb, J. P., Rahme, L. G., Lowry, S. F., Maier, R. V., Moldawer, L. L., Herndon, D. N., Davis, R. W., Xiao, W., Tompkins, R. G.; Inflammation and Host Response to Injury, Large Scale Collaborative Research Program (2013) Genomic responses in mouse models poorly mimic human inflammatory diseases. Proc. Natl. Acad. Sci. U. S. A. 110, 3507-3512.

Serkova, N. J., Standiford, T. J., Stringer, K. A. (2011) The emerging field of quantitative blood metabolomics for biomarker discovery in critical illnesses. Am. J. Respir. Crit. Care Med. 184, 647-655.

Shen, H. N., Lu, C. L., Yang, H. H. (2010) Epidemiologic trend of severe sepsis in Taiwan from 1997 through 2006. Chest 138, 298-304.

Sjöholm, K., Kilsgård, O., Teleman, J., Happonen, L., Malmström, L., Malmström, J. (2017) Targeted proteomics and absolute protein quantification for the construction of a stoichiometric host-pathogen surface density model. Mol. Cell. Proteomics 16, S29-S41.

Smolen, J. S., Aletaha, D., McInnes, I. B. (2016) Rheumatoid arthritis. Lancet 388, 2023-2038.

Sørensen, T. I., Nielsen, G. G., Andersen, P. K., Teasdale, T.W. (1988) Genetic and environmental influences on premature death in adult adoptees. N. Engl. J. Med. 318, 727-732.

Srinivasan, L., Page, G., Kirpalani, H., Murray, J. C., Das, A., Higgins, R. D., Carlo, W. A., Bell, E. F., Goldberg, R. N., Schibler, K., Sood, B. G., Stevenson, D. K., Stoll, B. J., Van Meurs, K. P., Johnson, K. J., Levy, J., McDonald, S. A., Zaterka-Baxter, K. M., Kennedy, K. A., Sánchez, P. J., Duara, S., Walsh, M. C., Shankaran, S., Wynn, J. L., Cotton, C. N.; Eunice Kennedy Shriver National Institute of Child Health and Human Development Neonatal Research Network (2017) Genome-wide association study of sepsis in extremely premature infants. Arch. Dis. Child. Fetal Neonatal Ed. 102, F439-F445.

Stephens, K. E., Miaskowski, C. A., Levine, J. D., Pullinger, C. R., Aouizerat, B. E. (2013) Epigenetic regulation and measurement of epigenetic changes. Biol. Res. Nurs. 5, 373-381.

Stüber, F., Petersen, M., Bokelmann, F., Schade, U. (1996) A genomic polymorphism with in the tumor necrosis factor locus influences plasma tumor necrosis factor-alpha concentrations and outcome of patients with severe sepsis. Crit. Care Med. 24, 381-384.

Su, L., Cao, L., Zhou, R., Jiang, Z., Xiao, K., Kong, W., Wang, H., Deng, J., Wen, B., Tan, F., Zhang, Y., Xie, L. (2013) Identification of novel biomarkers for sepsis prognosis via urinary proteomic analysis using iTRAQ labeling and 2D-LC-MS/MS. PLos One 8, e54237.

Su, L., Huang, Y., Zhu, Y., Xia, L., Wang, R., Xiao, K., Wang, H., Yan, P., Wen, B., Cao, L., Meng, N., Luan, H., Liu, C., Li, X., Xie, L. (2014) Discrimination of sepsis stage metabolic profiles with an LC/MS-MS-based metabolomics approach. BMJ Open Respir. Res. 1, e000056.

Sutherland, A. M., Walley, K. R., Russell, J.A. (2005) Polymorphisms in CD14, manose binding lectin, and Toll-like receptor- 2 are associated with increased prevalence of infection in critically ill adults. Crit. Care Med. 33, 638-644.

Průcha M.; Zazula R.; Russwurm S. 
Sweeney, T. E., Khatri, P. (2017) Benchmarking sepsis gene expression diagnostics using public data. Crit. Care Med. 45, 1-10.

Sweeney, T. E., Shidham, A., Wong, H. R., Khatri, P. (2015) A comprehensive time-course-based multicohort analysis of sepsis and sterile inflammation reveals a robust diagnostic gene set. Sci. Transl. Med. 7 , $287 \mathrm{ra71.}$

Talwar, S. (2006) Gene expression profiles of peripheral blood leukocytes after endotoxin challenge in humans. Physiol. Genomics 25, 203-215.

Tang, B. M., McLean, A. S., Dawes, I. W., Huang, S. J., Cowley, M. J., Lin, R. C. (2008) Gene-expression profiling of gram-positive and gram-negative sepsis in critically ill patients. Crit. Care Med. 36, 1125-1128.

Toft, P., Tønnesen, E. (2011) Immune-modulating interventions in critically ill septic patients: pharmacological options. Expert Rev. Clin. Pharmacol. 4, 491-501.

van der Poll, T., Opal, S. M. (2008) Host-pathogen interactions in sepsis. Lancet Infect. Dis. 8, 32-43.

van Vught, L. A., Wiewel, M. A., Hoogendijk, A. J., Frencken, J. F., Scicluna, B. P., Klein, K., Klouwenberg, P. M. C., Zwinderman, A. H., Lutter, R., Horn, J., Schultz, M. J., Bonten, M. M. J., Cremer, O. L., van der Poll, T. (2017) The host response in patients with sepsis developing intensive care unit-acquired secondary infections. Am. J. Respir. Crit. Care Med. 196, 458-470.

Venter, J. C., Adams, M. D., Myers, E.W., Li, P.W., Mural, R. J. (2001) The sequence of the genome. Science 291, 1304-1351.

Vincent, J. L., Sakr, Y., Sprung, C. L., Gerlach, H., Ranieri, V. M. (2006) Sepsis in European intensive care units: results of the SOAP study. Crit. Care Med. 34, 344-353.

Wang, Z. Z., Shi, K., Peng, J. (2017) Serologic testing of a panel of five antibodies in inflammatory bowel diseases: diagnostic value and correlation with disease phenotype. Biomed. Rep. 6, 401-410.

Watson, J. D., Crick, F. H. (1953) Genetical implications of the structure of deoxyribonucleic acid. Nature 171, 737-738.

Weiser, M., Simon, J. M., Kochar, B., Tovar, A., Israel, J.W., Robinson, A., Gipson, G. R., Schaner, M. S., Herfarth, H. H., Sartor, R. B., McGovern, D. P., Rahbar, R., Sadiq, T. S., Koruda, M. J., Furey, T. S., Sheikh, S. Z. (2018) Molecular classification of Crohn's disease reveals two clinically relevant subtypes. Gut 67, 36-42.

Wiel, E., Lebuffe, G., Vallet, B. (2002) Bacterial CpG DNA in septic shock. In: Yearbook of Intensive Care and Emergency Medicine.Vincent, J. L., Editor, pp. 388-398, Springer, Berlin.

Xiao, W., Mindrinos, M. N., Seok, J., Cuschieri, J., Cuenca, A. J., Gao, H., Hayden, D., Hennessy, L., Moore, E. E., Minei, J. P., Bankey, P. E., Johnson, J. L., Sperry, J., Nathens, A. B., Billiar, T. R., West, M. A., Brownstein, B. H., Mason, P. H., Baker, H.V., Finnerty, C. C., Jeschke, M. G., López, M. C., Klein, M. B., Gamelli, R. L., Gibran, N. S., Arnoldo, B., Xu, W., Zhang, Y., Calvano, S. E., McDonald-Smith, G. P., Schoenfeld, D. A., Storey, J. D., Cobb, J. P., Warren, H. S., Moldawer, L. L., Herndon, D. N., Lowry, S. F., Maier, R. V., Davis, R.W., Tompkins, R. G.; Inflammation and Host Response to Injury Large-Scale Collaborative Research Program (2011) A genomic storm in critically injured humans. J. Exp. Med. 208, 2581-2590.

Yu, K. H., Snyder, M. (2016) Omics profiling in precision oncology. Mol. Cell. Proteomics 16, 2525-2536.

Yu, S. L., Chen, H.W., Yang, P. C., Peck, K., Tsai, M. H., Chen, J. J., Lin, F.Y. (2004) Differential gene expression in gram-negative and gram-positive sepsis. Am. J. Respir. Crit. Care Med. 169, 1135-1143.

Zhang, X., Liu, D., Liu, Y. N., Wang, R., Xie, L. X. (2015) The accuracy of presepsin (sCD14-ST) for the diagnosis of sepsis in adults: a meta analysis. Crit. Care 19, 323-334.

Zimmerman, J. J., Sullivan, E., Yager, T. D., Cheng, C., Permut, L., Cermelli, S., McHugh, L., Sampson, D., Seldon, T., Brandon, R. B., Brandon, R. A. (2017) Diagnostic accuracy of a host gene expression signature that discriminates clinical severe sepsis syndrome and infection-negative systemic inflammation among critically ill children. Crit. Care Med. 45, e418-e425. 